\title{
The Postnatal Growth of the Alimentary Canal and the main long Bones of the Free- Extremities in the Albino Rat (Mus Norvegicus Albinus).
}

\author{
By \\ Drs. Koken Ito and Masao Fujihara. \\ From the Pathological Department of Okayama Medical College. \\ (Director Prof. Dr. Oto Tamura)
}

(Continued from No. 422.)

As to the growth of the alimentary canal, only the length, as previously mentioned, was measured in four portions: the stomach, cecum (including appendix vermiform) and small and large intestines. The weight was disregarded as it is very indeterminable on account of the content in the canal and moreover, its width is also indefinite. Hatai ${ }^{3}$ stated that the weight of the alimetary tract is represented by the following formula in albino rat:

Weight of alimentary tract

$$
=0.0245 \text { Body-weight }+4.720 \text { Log (Body-weight }+7)-5.753 \text {. }
$$

The distance between the cardiac and the pylorus was measured for the stomachlength and the content in the stomach was untouched. This measuring may not be proper, but the stomach of such young rat is always filled with some contents nearly to the same extend and so the content will not disturb the measuring. There are several methods of measuring the stomach besides the above one; the length of greater curvature or lesser curvature, or the dimension of stomach etc., are also applied. On the first day after birth, the stomach is already filled with milk and its white color is clearly seen through the wall of the skin as proviously described. In the intestine, especially in the large intestine, the dark green substance, the meconium is detected. As a rule, all the portions are developed proportionately and particularly after having opened their eyes on about fifteenth day, they make remarkable progress. On this occasion, the stomach holds some content besides milk and also the intestinal contents 
grow in volume and especially the cecum is markedly enlarged, measuring its width nearly three times as large as that of the small intestine though its length is not distinctly extended. The rate of increase between the average length of each portion on the first day after birth and that of the same portion on the thirtieth day is as follows:-

\begin{tabular}{l|c|c|l|c|c}
\hline & 1st day & 30th day & & 1st day & 30th day \\
\hline Body-length & 1 & 2.1 & Cecum (includes appendix) & 1 & 5.8 \\
Stomach-length & 1 & 2.9 & Large intestine-length & 1 & 3.2 \\
Small intestine-length & 1 & 2.6 & & &
\end{tabular}

The following table VIII shows the proportional length of the above four portions compared with the body-length.

Table VIII.

\begin{tabular}{c|c|c|c|c|c}
\hline Days after birth & Body length & Stomach length & $\begin{array}{c}\text { Small intestine } \\
\text { length }\end{array}$ & Cecum length & $\begin{array}{c}\text { Large intestin } \\
\text { length }\end{array}$ \\
\hline 1st & 1 & 0.18 & 3.96 & 0.08 & 0.57 \\
2nd & 1 & 0.18 & 4.08 & 0.10 & 0.55 \\
3rd & 1 & 0.20 & 4.13 & 0.09 & 0.59 \\
4th & 1 & 0.19 & 4.23 & 0.11 & 0.63 \\
5th & 1 & 0.21 & 4.33 & 0.12 & 0.67 \\
6th & 1 & 0.20 & 4.27 & 0.12 & 0.64 \\
7th & 1 & 0.23 & 4.58 & 0.10 & 0.73 \\
8th & 1 & 0.21 & 4.24 & 0.11 & 0.70 \\
9th & 1 & 0.19 & 4.30 & 0.10 & 0.73 \\
10th & 1 & 0.20 & 4.00 & 0.10 & 0.68 \\
11th & 1 & 0.19 & 4.07 & 0.12 & 0.70 \\
12th & 1 & 0.20 & 4.14 & 0.12 & 0.72 \\
13th & 1 & 0.20 & 4.20 & 0.13 & 0.71 \\
14th & 1 & 0.19 & 4.35 & 0.13 & 0.70 \\
15th & 1 & 0.17 & 4.24 & 0.13 & 0.74 \\
20th & 1 & 0.20 & 4.05 & 0.14 & 0.73 \\
25th & 1 & 0.23 & 4.67 & 0.15 & 0.72 \\
30th & 1 & 0.24 & 4.92 & 0.21 & 0.85 \\
& & & & \\
\hline
\end{tabular}

Still, the following table shows the average number of the various portions in both sexes.

As above table illustrates, in all the portions, the male is always superior to the female, with an exception that the former's stomach is slightly smaller than that of the latter. Comparing this relation with that of the human beings, it is obvious that the 


\begin{tabular}{|c|c|c|c|c|}
\hline & & & Total number & Average \\
\hline \multirow[t]{2}{*}{ Body-length : } & ales examined & 51 & 372.0 & 7.3 \\
\hline & males examined & 57 & 402.0 & 7.1 \\
\hline \multirow[t]{2}{*}{ Stomach-length : } & ditto & & 76.1 & 1.3 \\
\hline & ditto & & 81.0 & 1.4 \\
\hline \multirow[t]{2}{*}{ Small intestine-length : } & ditto & & 1650.3 & 32.4 \\
\hline & ditto & & 1698.2 & 29.8 \\
\hline \multirow[t]{2}{*}{ Cecum: (includes appendix vermiform) } & ditto & & 48.0 & 0.9 \\
\hline & ditto & & 48.0 & 0.8 \\
\hline \multirow[t]{2}{*}{ Large intestine-length : } & ditto & & 269.0 & 5.3 \\
\hline & ditto & & 273.0 & 4.8 \\
\hline
\end{tabular}

male is always superior to the female. On this occasion, however, the measuring of the fully matured human-intestines is applied and we failed to find out a literalure on the same subject which was investigated systematically in young and accordingly, the comparison of the intestines between the young albino rat and the fully matured human beings may not be proper.

For comparison, the following table in human beings is shown:-

The length of the small intestine.

\begin{tabular}{c|l|c|c|c|c}
\hline $\begin{array}{c}\text { Investigators' } \\
\text { name }\end{array}$ & & $\begin{array}{c}\text { Total number } \\
\text { examined }\end{array}$ & Longest length & Shortest length & Average \\
\hline \multirow{2}{*}{ Kubo19 } & man & 40 & 888.30 & 394.80 & 645.02 \\
& woman & 11 & 924.49 & 394.80 & 612.91 \\
Sato21 & man & 5 & - & - & 641.00 \\
& woman & 5 & - & - & 629.60 \\
Sugita21 & man & 82 & 1100.00 & 164.00 & 6078.86 \\
& woman & 38 & 898.00 & &
\end{tabular}

The length of the large intestine.

\begin{tabular}{l|l|l|l|r|r} 
Kubo19 & man & 38 & 204.63 & 98.70 & 144.26 \\
& woman & 11 & 200.69 & 90.74 & 137.60 \\
Sugita?1 & man & 82 & 222.00 & 116.00 & 173.21 \\
& woman & 38 & 216.00 & 98.00 & 166.96
\end{tabular}

The ratio between the small and large intestines is as follows:-

$$
\begin{array}{lcll}
\text { Male : } & \text { Large intestine : Small intestine } & =1: 6.1 \\
\text { Female: } & \text { ditto } & =1: 62 \\
\text { Average: } & \text { ditto } & =1: 6.15
\end{array}
$$

In human beings, Suzuki $i^{18}$ compared the large intestine with the small intestine as 
follows :-

$\begin{array}{lcl}\text { Man: } & \text { Large intestine : Small intestine } & =1: 4.0 \\ \text { Woman: } & \text { ditto } & =1: 3.7 \\ \text { Average: } & \text { ditto } & =1: 39\end{array}$

It is seen that the deviation between the large and the small intestines in human beings is smaller than that of the rat.

The ratio between the body-length and the small intestine is as fullows:-

$\begin{array}{lcl}\text { Male: } & \text { Body-length : Small intestine } & =1: 44 \\ \text { Female : } & \text { ditto } & =1: 4.2 \\ \text { Average } & \text { ditto } & =1: 43\end{array}$

Miyake and Soeshima ${ }^{20}$ compared the above ratio in human beings as follows:Miyake: Body-length : Small intestine $=1: 4.2$

Soeshima: ditto $\quad=1: 4.1$

Lastly, the ratio between the total lengths of small and large intestines and the body-length is as follows:-

$\begin{array}{lcc}\text { Male: } & \text { Body-length : Total length of intestines } & =1: 5.2 \\ \text { Female: } & \text { ditto } & =1: 49 \\ \text { Average : } & \text { ditto } & =1: 5.0\end{array}$

Kubo's ${ }^{19}$ comparison in human beings is as follows:-

$\begin{array}{lcl}\text { Man : } & \text { Body-length : Tolal length of intestines } & =1: 5.0 \\ \text { Woman: } & \text { ditto } & =1: 4.9 \\ \text { Average: } & \text { ditto } & =1: 50\end{array}$

It is enthusiastically hoped that these records may serve as a standard in investigating this line of study on the albino rat.

In ending, we beg to record our thanks to Professors Tamura and Tanabe who were kind enough to look over this manuscript. (Completed on December 25, 1924.)

\section{Literatures cited.}

1) Donaldson, A comparison of the white rat with man in respect to the growth of the entire body. Boas Anniversary vol. New York, $1911 . \quad$ 2) Hatai, The growth of the body and organs in albino rats fed with a lipoid-free ration. Anat. Record, Vol. 9, p. 1,1915. 3) Hatai, On the weights of the abdominal and the thoracic viscera, the sex glands, ductless glands and the eyeballs of the albino rat. Am. J. of Ant., Vol. 16, No. 2, p. 251, 1913. 4) Hatai, On the infuence of exercise on the/growth of organ in the albino rat. Anat. Record, Vol. 9, p. 674, 1915.5 5) King, On the weight of the albino rat at birth and the factors that influence it. Anat. Record, Vol. 9, p. 213,1915 . 6) King and Stotsenburg, On the normal sex ratio and the size of the litter in the albino rat. Anat. Record, Vol. 9, p. 403, 1915.7 7) Slonaker, The normal activity of the albino rat from birth to natural death, its rate of growth and the duration of life. J. Animal Behavior, 
Vol. 2, 1912. 8) Stotsenburg, The growth of the fetus of the albino rat from the thirteenth to the twenty second day of gestation. Anat. Re. ord, Vol. 9, p. 667, 1915. 9) Feldman, The principles of ante-natal and post-natal child physiology, 1920. 10) Jackson, Post-natal growth and variability of the body and of the various organs in the albino rat. Am. J. of Anat., Vol. 15, p. 1, 1913. 11) Holt and Howland, Disease of infancy and childhood, 1922. 12) Weisserberg; Das Wachstum des Menschen, 1911 . 13) Robertson, Am. J. of Physiology, Vol. 37, p. 1, $1915 . \quad$ 14) Mishima, Das Wachstum des Kindes in Japan, $1902 . \quad 15)$ Kominami, Jitsuyo Hoigaku, 1923. 16) Ando, Kokka Igaku Zasshi, No. 435, 1923. 17) Takata, Kyoto Igakkai Zasshi, No. 5, p. 395, 1917. 18) Hasebe, Tohoku Igakkaishi, No. 2, Band 2. 19) Kubo, Nippon Shokakigakkai Zasshi, Vol. 5, Nos. 2, 3, 4. 20) Miyake, Nisshin Igaku, Vol. 7, No. 1. 21) Sugita, Tohoku Igakkai Zasshi, Nos. 76 and 77. 22) Okamoto, Chugai Ijishimpo, No. 920.

C䙐色色汗应ノ一例ニッキテ. Schoch, Über einen Fall von branner Chromidrose.

(Derınat. Wochenschr. Bd. 80 Nr. I, 1925.)

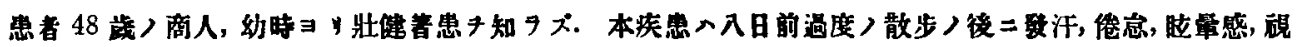

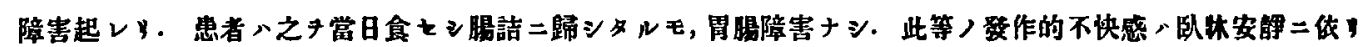

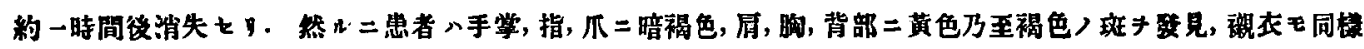

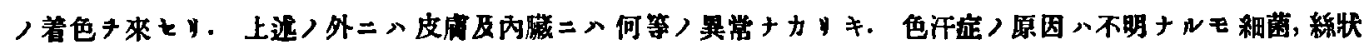

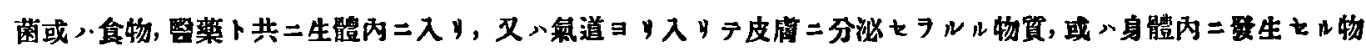

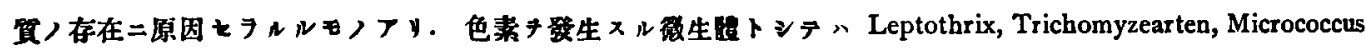

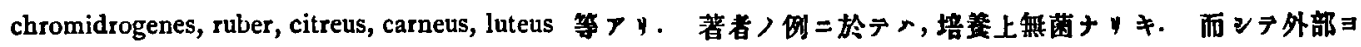

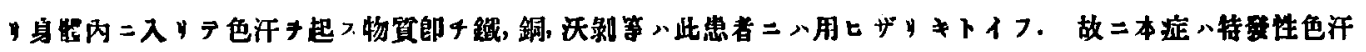

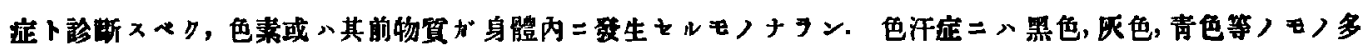

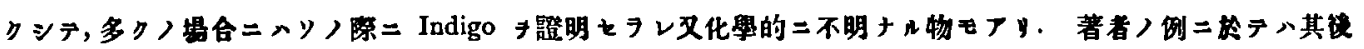

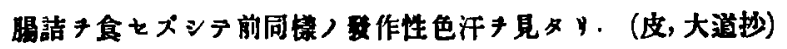

